\title{
Neuroticism, Agreeableness, and Conscientiousness and the Relationship with Individual Taxpayer Compliance Behavior
}

\author{
Brian Huels \\ University of Wisconsin-Whitewater \\ K. Praveen Parboteeah \\ University of Wisconsin-Whitewater
}

Within the Big Five personality framework, past research has found that neuroticism, agreeableness, and conscientiousness tend to display a relationship with ethical behavior (Sacket \& Wanek, 1996; Kolz, 1999; Kalshoven, Den Hartog, \& DeHoogh, 2011). Although past research has explored the relationship between white-collar crime and personality (Blickle, Schlegel, Fassbender, \& Klein, 2006; Turner, 2014), this study seeks to more narrowly look at the influence that personality (specifically, neuroticism, agreeableness, and conscitiousness) has on taxpayer compliance. As hypothesized, results provide support that taxpayer compliance behavior decreases when higher level of neuroticism and conscientiousness are present.

\section{INTRODUCTION}

"Tax evasion is a widespread phenomenon and continues to be a problem for many countries" (Tsakumis, Curatola, \& Porcano, 2007, p. 132). Within the U.S., the tax gap, defined as the difference between what taxpayers owe and what is paid on a voluntarily and timely basis (Andreoni, Erard, \& Feinstein, 1998), amounts to approximately $\$ 406$ billion per year (Internal Revenue Service, 2016a). Sixty-five percent of this amount ( $\$ 264$ billion) can be sourced to the underreporting of income by individual taxpayers. Furthermore, "Although the IRS has initiated several initiatives to address the tax gap," (Washburn \& Fisher, 2012, p. 31) the tax gap has not seen any significant reduction in size. Given this information, studies aiming to better understand the compliance behavior of taxpayers are critical. Past tax research has referenced the inclusion of personality as a predictor variable. However, upon review, the actual items of measure within these studies were not necessarily personality variables as is understood by extent research. Rather, these studies included variables such as taxpayer conformity, responsibility, value orthodoxy, risk propensity, alienation, competitive orientation, moral reasoning, and egoism, to name a few (Collins, Milliron, \& Toy, 1992; Hessing, Elffers, \& Weigel, 1988; Tittle, 1977; Trivedi, Shehata, \& Lynn, 2003; Webley, Cole, \& Eidjar, 2001). As such, although these authors have used the term personality loosely, none of the past studies have specifically looked at the relationship between personality traits and taxpayer behavior.

The Big Five personality traits have been successfully shown to predict behavioral outcomes in areas such as schooling, wages, crime, leadership, and job performance (Borghans, Duckworth, Heckman, \& 
Weel, 2008). Related to individual taxpayer compliance, personality (specifically the Big Five personality traits) has received "only a limited amount of research" (Taggar \& Parkinson, 2007; Turner, 2014, p. 59) as being a possible explanatory variable. As the Big Five model is "unquestionably, the most ubiquitous and widely accepted trait framework in the history of personality psychology" (Funder, 2001; Judge \& Zapata, 2015, p. 1150), a gap exists in understanding how these personality traits influence individual taxpayer compliance. Using the Big Five framework, past research has found that three of the five traits (agreeableness, conscientiousness, and neuroticism) are the most relevant when exploring unethical behavior (Sacket \& Wanek, 1996; Kolz, 1999, Kalshoven, Den Hartog, \& DeHoogh, 2011). Therefore, this study seeks to answer the question: How are the personality traits of neuroticism, agreeableness, and conscientiousness related to individual taxpayer compliance intentions?

\section{LITERATURE REVIEW AND THEORY DEVELOPMENT}

\section{Taxpayer Behavior}

Compliant taxpayers pay their fair share of taxes, as defined by government, in a timely manner. Noncompliance behavior results from the failure, intentional or unintentional, to meet these obligations. Unintentional acts include mistakes related to mathematical errors, incorrect form preparation, lack of knowledge of the topic, as well as memory lapse about the situational facts (Loftus, 1985; Smith \& Kinsey, 1987). Intentional acts, typically viewed as unethical in nature, are often referred to as tax cheating, tax fraud and tax evasion (Weigel, Hessing, \& Elffers, 1987).

Economic deterrence and fiscal psychology are two common areas of study related to tax compliance. Both of these avenues, however, tend to overestimate the amount of tax evasion (Hasseldine \& Li, 1999). Other research has looked at enforcement initiatives and the relationship with taxpayers' fear of detection (Davis, Hecht, \& Perkins, 2003). These studies showed that taxpayers who fear being audited or caught are more likely to comply. Researchers have also looked at the demographics of taxpayers (McGee \& Tyler, 2006; Pickhardt \& Prinz, 2014) and the majority of these studies have shown that minor correlations with illegal tax filing choices exist for individuals who are male, younger, wealthier, and with more education (Ragatz, Fremouw, \& Baker, 2012). However, despite the abundance of studies examining antecedents of taxpayer compliance, this is the first that we are aware to specifically incorporate the Big Five personality traits of neuroticism, agreeableness, and conscientiousness.

\section{Personality Traits}

We define personality as a "predisposition to behave systematically" (Taggar \& Parkinson, 2007, p. 123). Personality has been shown to be a key factor in understanding behavior of indivduals when placed in certain situations (John, Robins, \& Pervin, 2008) and has been shown to be an important antecedent in a variety of settings, such as, job performance, social media usage, technology acceptance, use of alcohol, and consumer brand preference (Hakulinen, Elvainio, Batty, Virtanen, Kivimaki, \& Jokela, 2015; Lin, 2010; Ryan \& Xenos, 2011; Svendsen, Johnsen, Almas-Sorensen, \& Vitterso, 2011; Tett, Jackson, \& Rothstein, 2001). As the tax filing process is the culmination and combination of a variety of situations and decisions that a taxpayer has been through, understanding how personality might influence or predict this behavior is of interest.

To build a base for understanding the influence that personality has on taxpayer behavior, we use three of the five personality traits contained within the Big Five Inventory (BFI). Compared to other instruments, such as the Myers-Briggs Type Indicator ${ }^{\circledR}$ (MBTI), A/B personality types, and Big Seven traits (Alalehto, 2003; Elliott, 2010; Taggar \& Parkinson, 2007), past research has demonstrated significant predictive validity of the BFI measure - making it the "superior indicator when answering questions of a causative or explanatory nature" (Goldberg, 1982; Taggar \& Parkinson, 2007; Turner, 2014, p. 64).

Next we define neuroticism, conscientiousness, and agreeableness and discuss how each specific personality trait is related to tax non-compliance behavior. 


\section{Hypotheses}

Neuroticism

Neuroticism "represents individual differences in the tendency to experience distress, and in the cognitive and behavioral styles that follow this tendency" (McCrae \& John, 1992, p. 195). Higher levels of neuroticism would be reflected by characteristics of "tension, depression, frustration, guilt, and selfconsciousness" (McCrae \& John, 1992, p. 195). Alternatively, less neurotic individuals would tend to be defined as being calm, relaxed and more emotionally stable.

Although Turner (2014) found that more neurotic individuals were more compliant (in the context of not committing white-collar crime) and Bratton and Strittmatter (2013) found that more neurotic individuals held more ethical perceptions, the majority of past studies have shown the opposite. Specifically, higher levels of neuroticism are associated with less ethical behavior. Kalshoven et al., (2011) found that more neurotic individuals displayed less ethical leadership behaviors. Furthermore, Koltz (1999) found that more neurotic employees are more likely to engage in retail theft and other counterproductive workplace behaviors. In line with these findings, we hypothesize here that individuals who display higher levels of neuroticism will be more likely to engage in tax non-compliance. Such people are less emotionally stable; therefore, they may be more comfortable making deviant choices regarding non-compliance. Alalehto (2003) showed a relationship between illegal behavior and individuals who rank higher on the scale of neuroticism. The study showed that neurotic individuals may struggle to see "what is right or wrong" (2003, p. 350) and may carry tones of insecurity and immaturity. The inability to see what is right or wrong, combined with behavior associated with immature individuals, could very easily lead to decisions of illegal behavior, including tax non-compliance.

The opportunity to be non-compliant exists for all taxpayers. However, individuals who are more neurotic will be more comfortable making a non-compliant choice and dealing with any resulting distress. Individuals that are calmer and relaxed (i.e., more emotionally stable) may find it more difficult to make decision of illegal behavior as it changes the status quo of their typical mindset. Our hypothesis is consistent with Alalehto's (2003) findings of higher neuroticism being related to tax non-compliance. It is expected that when looking specifically at the decision an individual taxpayer will make related to the reporting of taxable income, a significant positive relationship will emerge related to the level of neuroticism and taxpayer non-compliance. Therefore:

Hypothesis 1: Higher neuroticism will be associated with a higher likelihood to engage in tax noncompliance behavior.

\section{Agreeableness}

Agreeableness is best understood by looking at traits of social adaptability, likability, compliance, and love (Pervin \& John, 1999). High agreeableness scorers tend to be sympathetic, considerate, warm, and compassionate. Lower scorers in this dimension are more critical, skeptical, and are more likely to display condescending behavior (McCrae \& Costa, 2003).

Past research has shown that white-collar criminals are likely to score lower on this trait; specifically, lower scorers would be more likely to hold grudges, doubt others, and be defensive in the choices and actions they make (Alalehto, 2003). Turner (2014) found similar outcomes. We argue similarly that agreeableness should be positively related to taxpayer compliance.

Individuals that score high on the scale of agreeableness are more likely to be compassionate and caring. Compassionate and caring individuals, in turn, are more likely to want to do the right thing. These same individuals are expected to be sympathetic and considerate. Being sympathetic would lay claim that individuals are more likely to be conscious of the harm that occurs to the social wellbeing of others by not paying their fair share of taxes. Based on these arguments, it is expected that individuals with higher agreeableness are more likely to engage in proper tax compliance. Individuals who score lower in agreeableness may be more critical of the tax filing process and the end use of the tax revenue generated, resulting in decisions of non-compliance. This is stated by the following hypothesis: 
Hypothesis 2: Lower agreeableness will be associated with a higher likelihood to engage in tax noncompliance behavior.

\section{Conscientiousness}

Conscientiousness is best described as a "socially prescribed impulse control that facilitates task-and goal-directed behavior" (Pervin \& John, 1999, p. 117). Higher-scoring, more conscientiousness, individuals are likely to behave more ethically, responsibly, and maintain higher levels of aspiration (McCrae \& Costa, 2003). Conversely, lower-scoring individuals will be self-indulgent and less likely to apply moral principles in making decisions (McCrae \& Costa, 2003; Taggar \& Parkinson, 2007).

Compliance with rules and regulations is something that involves a legal, moral, and ethical decisionmaking process. Responsible individuals will be more likely to obey the rules, aspire to be moral citizens, and make decisions that benefit those around them. In addition, conscientious individuals would be expected to behave ethically and responsibly. More self-centered individuals will be less concerned with the ethics behind compliance and more focused on personal gain.

In a tax setting, it is obvious that the ethical and responsible behavior would be decisions of compliance. In addition, when considering levels of aspiration, few individuals looking to aspire socially would seek out paths leading to morally subpar behaviors. As tax "compliance is undoubtedly motivated by moral beliefs" (Hite, 1996, p. 77), it is expected that individuals who display higher levels of conscientiousness will show increased tax compliance. This position is summarized in the following hypothesis:

Hypothesis 3: Lower conscientiousness will be associated with a higher likelihood to engage in tax noncompliance behavior.

\section{METHODOLOGY}

\section{Sample and Data Collection}

The study employed an online questionnaire using Amazon's Mechanical Turk (MTurk) consumer panel to gather information from taxpayers regarding their personality, taxpayer compliance intent, and a variety of other questions. 388 total responses were gathered from Turkers from the U.S. that held a past approval rate of $70 \%$ on previous surveys. From this number, 82 surveys were removed for a variety of reasons including: embedded attention questions answered incorrectly (15), internet protocol outside of the United States (5), indicated they did not file a tax return (4), missing demographc question(s) (50), survey was completed in a very short time frame (4), and appearent inconsistencies in answers (4). Removal of these responses left 306 responses. As mean substitution using the total collected sample did not provide significantly different findings, the narrowed sample was deemed suitable. Additional sample refinement was done to ensure that respondents were aware of proper tax law. This refinement was based upon how respondents answered the question: "If a taxpayer receives cash for miscellaneous jobs performed during the year, what is the proper treatment for tax purposes." The correct answer for this question is that "any and all cash received should be included in taxable income?" Therefore, only responses that met this criterion were analyzed to provide assurance that we were looking at taxpayer behavior of individuals that understand underlying tax law. This resulted in 137 responses being analyzed. Demographics of the analyzed sample are in Table 1. 


\section{TABLE 1}

\section{SAMPLE DEMOGRAPHICS}

\begin{tabular}{|c|c|c|c|c|c|}
\hline Category & $\begin{array}{l}\text { Sample } \\
\text { number }\end{array}$ & $\begin{array}{c}\text { Sample } \\
\text { percentage }\end{array}$ & Category & $\begin{array}{l}\text { Sample } \\
\text { number }\end{array}$ & $\begin{array}{c}\text { Sample } \\
\text { percentage }\end{array}$ \\
\hline \multicolumn{6}{|c|}{ Age } \\
\hline 18 to 24 years & 1 & $0.7 \%$ & 45 to 54 years & 25 & $18.2 \%$ \\
\hline 25 to 34 years & 45 & $32.8 \%$ & 55 to 64 years & 22 & $16.1 \%$ \\
\hline 35 to 44 years & 38 & $27.7 \%$ & 65 or older & 6 & $4.4 \%$ \\
\hline \multicolumn{6}{|c|}{ Household Income } \\
\hline Less than $\$ 25,000$ & 29 & $21.2 \%$ & $\$ 75,000$ to $\$ 99,000$ & 17 & $12.4 \%$ \\
\hline$\$ 25,000-\$ 49,999$ & 40 & $29.2 \%$ & Over $\$ 100,000$ & 12 & $8.7 \%$ \\
\hline$\$ 50,000$ to $\$ 74,999$ & 39 & $28.5 \%$ & & & \\
\hline \multicolumn{6}{|c|}{ Gender } \\
\hline Male & 69 & $50.4 \%$ & Female & 68 & $49.6 \%$ \\
\hline \multicolumn{6}{|c|}{ Education } \\
\hline Did Not Finish H.S. & 1 & $0.7 \%$ & Bachelor's degree & 57 & $41.6 \%$ \\
\hline High School Graduate & 17 & $12.4 \%$ & Master's degree & 9 & $6.6 \%$ \\
\hline Some College & 29 & $21.2 \%$ & Doctoral degree & 5 & $3.6 \%$ \\
\hline Associate's degree & 19 & $13.9 \%$ & & & \\
\hline
\end{tabular}

Note. Sample demographics are based on results of 137 analyzed responses. IRB approval was obtained prior to gathering of information.

\section{Measurement of Variables}

Dependent Variable

This study's dependent variable of interest is taxpayer compliance behavior. This variable was measured by analyzing respondents' answer to how much cash income they would declare when filing a tax return build on a hypothetical tax fact pattern. As $\$ 264$ billion, over $65 \%$ of the net tax gap, is attributed to the underreporting of individual income tax (Internal Revenue Service, 2016a), specific attention to the reporting of cash income is worthwhile.

Respondents were first primed with a story to introduce the question related to declaration of cash income. The story introduced a fictitious character, Jesse, who had recently moved from Florida to Illinois to start a job as a graphic designer working for a large company. Working this job, Jesse earned $\$ 50,000$ in wages on which an appropriate amount of federal income tax was withheld. In addition to the full-time job, Jesse also performed some small graphic design work for various people in the neighborhood for which cash was received. During the past year, this side work amounted to a total of $\$ 5,000$. Instructions to survey takers asked them to assume the role of Jesse. Moving past the short story, via placement of a slider bar, respondents were asked to respond with the decision that would be made related to how much of the side design income they would report on their tax return. Submitted answers could range from zero dollars (complete non-compliance) to $\$ 5,000$ (100\% compliance).

\section{Neuroticism, Agreeableness, and Conscientiousness Personality Traits}

To measure the personality traits, this study used a 20-item International Personality Item Pool (MiniIPIP) scale, which consisted of four indicator items per trait. Results were captured for all of the Big Five personality traits. As three of the traits have been shown to be most relevant with ethical decisions they are the primary focus of this study. The scale allowed respondents to provide answers ranging from 1 
(strongly disagree) to 5 (strongly agree). This shorter measure, based on a 50-item pool (Goldberg, 1999), has shown proper validity in past studies (Donnellan, Oswald, Baird, \& Lucas, 2006).

\section{Control Variables}

After capturing questions related to the Big Five traits, several control variables were captured. Specifically, the following demographic variables were controlled for: age, gender, income level, education level, and employment status. Past literature reviews have summarized the commonality of inclusion of these variables (Jackson \& Milliron, 1986; Richardson \& Sawyer, 2001).

Also, to help provide assurance that respondents were attentive throughout the completion of the questionnaire, three check questions were embedded at various intervals. These questions were: "Mark your selection strongly disagree for this line"; "Please answer this question by selecting 60\%"; and "Mark a false response for this line item." Past research has supported using these types of attention or instructional manipulation check questions to identify inattentive participants (Aust, Diedenhofen, Ullrich, \& Musch, 2012; Hauser \& Schwarz, 2016; Oppenheimer, Meyvis, \& Davidenko, 2009).

Finally, questions were asked to try and capture the level of risk that each respondent would be comfortable with as well as his/her underlying level of desire to reduce tax liability. As the risk of audit is low (Internal Revenue Service, 2016b), capturing these variables is important to control for in seeking to isolate any existing relationship with personality. Using a modified measure adopted from Bobek, Hageman, and Kelliher (2013), risk was captured using a composite score resulting from three questions that asked respondents to provide the level of certainty that they would seek before they would take a certain position on their tax return. The three questions were asked using an 11-point Likert scale. As presented, a higher score would equal a lower level of willingness to take risk. For ease of interpretation, this variable was reverse coded; therefore, a higher score reflects a higher level of risk tolerance. The desire that each respondent had to reduce their tax bill was captured using a single question of "I would really enjoy reducing my tax bill, regardless of whether it was illegal or not." Answers were scored on a 7 point Likert Scale $(1=$ Strongly Disagree; $7=$ Strongly Agree). The inclusion of this question provides context as to each respondents desire to reduce his/her tax liability.

\section{RESULTS}

Analysis of survey responses related to the Big Five personality traits, began with factor analysis of the 20-item Mini-IPIP scale. Principal component analysis was performed using Oblimin with Kaiser normalization rotation showed proper loading of each of the four questions on their respective personality trait. Cross-loading of questions was not an issue and all loaded on the anticipated factor, at or above .688. Cronbach alpha scores for each of the scales were as follows: extraversion (.884), neuroticism (.879), agreeableness (.893), conscientiousness (.793), and openness to experience (.820). These resulting scores, all above .70, support using the indicators (Cortina, 1993). Acknowledging the proper loading of the measures on the respective Big Five personality traits, a composite score for each respondent was calculated by averaging responses to each of the four measures per personality trait. For purposes of this study, specific attention is given to the personality traits of neuroticism, agreeableness, and conscientiousness as these traits have been most commonly linked in past research as predictors of behavior (Kolz, 1999; Kalshoven, Den Hartog, \& DeHoogh, 2011).

Descriptive statistics and correlation information for the resulting mean scores, control variables, and tax gap of unreported cash income are presented in the correlation matrix shown in Table 2. 


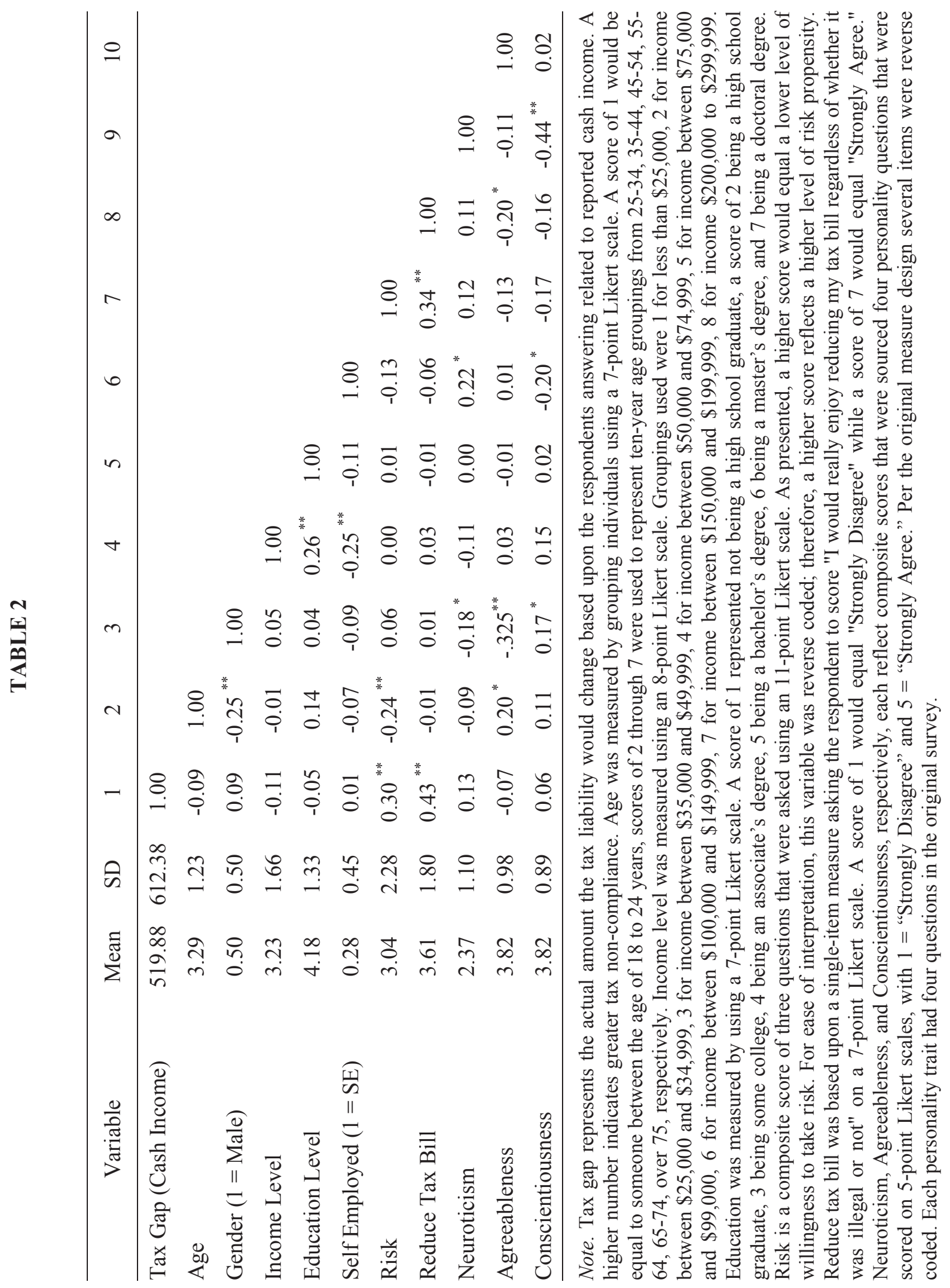

Journal of Accounting and Finance Vol. 19(4) 2019187 
To test hypotheses, a base statistical model was run to ensure that any additional analysis, including personality, could be compared to gauge whether meaningful improvement occurred. The base model yielded an adjusted $\mathrm{R}^{2}$ of $.196, \mathrm{~F}(7,129)=5.722, p<.001$. Results of the base model are presented in the left column of Table 3 . The next step in analysis was to look at the relationship that resulted from adding the personality traits of neuroticism, agreeableness, and conscientiousness. The results of the ordinary least squares (OLS) regressions can be seen in Table 3.

TABLE 3

OLS PARAMETER ESTIMATES

\begin{tabular}{|c|c|c|}
\hline Variable $^{a b}$ & $\begin{array}{c}\text { Base } \\
\text { Model }\end{array}$ & $\begin{array}{c}\text { Base Model } \\
\text { with Personality }\end{array}$ \\
\hline Constant & $\begin{array}{c}57.553 \\
(255.337)\end{array}$ & $\begin{array}{l}-1043.778 \\
(449.396)\end{array}$ \\
\hline Age & $\begin{array}{l}-11.160 \\
(41.960)\end{array}$ & $\begin{array}{l}-22.900 \\
(41.574)\end{array}$ \\
\hline Gender & $\begin{array}{l}102.805 \\
(97.863)\end{array}$ & $\begin{array}{c}117.737 \\
(103.143)\end{array}$ \\
\hline Income & $\begin{array}{l}-41.416 \\
(30.263)\end{array}$ & $\begin{array}{l}-49.716 \\
(29.766)\end{array}$ \\
\hline Education & $\begin{array}{c}-7.187 \\
(37.283)\end{array}$ & $\begin{array}{c}-4.108 \\
(36.464)\end{array}$ \\
\hline Employment & $\begin{array}{c}37.486 \\
(109.743)\end{array}$ & $\begin{array}{c}49.871 \\
(109.769)\end{array}$ \\
\hline Risk & $\begin{array}{l}44.546 * \\
(22.938)\end{array}$ & $\begin{array}{l}48.374 * \\
(22.562)\end{array}$ \\
\hline Reduce Tax Bill & $\begin{array}{c}128.921 * * * \\
(27.829)\end{array}$ & $\begin{array}{c}141.278 * * * \\
(27.876)\end{array}$ \\
\hline Neuroticism & & $\begin{array}{l}94.298 * \\
(48.122)\end{array}$ \\
\hline Agreeableness & & $\begin{array}{c}57.916 \\
(51.866)\end{array}$ \\
\hline Conscientiousness & & $\begin{array}{c}168.014 * \\
(59.408)\end{array}$ \\
\hline Sample Size (n) & 137 & 137 \\
\hline R-Square & 0.237 & 0.292 \\
\hline Adjusted R-Square & 0.196 & $0.236^{\mathrm{d}}$ \\
\hline F (sig.) & $5.722 * * *$ & $5.192 * * *$ \\
\hline Maximum VIF ${ }^{c}$ & 1.236 & 1.338 \\
\hline
\end{tabular}

Note: $\mathrm{N}=137$

${ }^{\text {a }}$ Dependent variable is tax gap related to cash income not reported on tax return.

${ }^{\mathrm{b}}$ Standard errors are given in parenthesis. Unstandardized coefficients are displayed.

${ }^{\mathrm{c}} \mathrm{VIF}=$ variance inflation factor

${ }^{\mathrm{d}}$ Addition of personality traits provide a significant model improvement $(p<.05)$.

$* p<.05 . * * * p<.001$. 
The addition of the personality traits provided a significant improvement $(p<.05)$ in model fit, raising the adjusted $\mathrm{R}^{2}$ to $.236, \mathrm{~F}(3,126)=5.192, p<.001$. As seen in the right column of Table 3 , the personality traits of neuroticism $(\beta=94.298, p<.05)$ and conscientiousness $(\beta=168.014, p<.05)$ displayed significant positive relationships with taxpayer non-compliance. These findings substantiated the hypothesized relationships between neuroticism (H1) and conscientiousness (H3) and tax noncompliance. Specifically, taxpayer's that are more neurotic and/or more conscientious will be more likely to engage in non-compliant behavior. The personality trait of agreeableness did not show a significant relation thus leaving H2 unsupported. Post-hoc analysis looked at a model that included all of the Big Five personality traits. As suspected, and in line with past research, the traits of extraversion and openness to experiences did provide a significant adjustment to the model.

Other findings of this study indicate that the level of risk that a taxpayer is willing to take when taking a position on a tax return has a positive relationship with non-compliance. Specifically, the higher the risk that a taxpayer is comfortable with the more likely they will make a decision of non-compliance $(\beta=48.374, p<.05)$. Finally, the greater the desire a taxpayer has to reduce their tax bill the more likely he/she will be to make a decision of non-compliance to obtain this goal $(\beta=141.278, p<.001)$. Although in the context of academic cheating, this mirrors the finding of $\mathrm{Yu}$, Glanzer, Sriram, Johnson, \& Moore. (2017) who found a similar relationship between student attitude and cheating.

\section{DISCUSSION}

This study considered the relationship between several of the Big Five personality traits and taxpayer compliance intentions. Specifically, the personality traits of neuroticism, agreeableness, and conscientiousness were analyzed. Having received limited attention in previous tax literature, some unique findings were discovered.

Concerning the Big Five personality traits, this study showed support for a relationship between neuroticism and conscientiousness. The hypothesized relationship between taxpayer non-compliance and agreeableness was not supported. A possible explanation may come from the social component inherent to agreeableness. Essentially, since agreeable individuals have a strong desire to maintain positive relationships with others and avoid conflict (e.g. Barrick, Stewart, \& Piotrowski, 2002; Costa \& McCrae, 1992; Judge \& Zapata, 2015), the social component would suggest they would avoid tax non-compliance. However, filing one's taxes is a very private matter. Perhaps the private nature of tax compliance explains why agreeableness's social component is not influential in this case.

Given the above results, this study makes several important contributions. A foundational component of this research was built on the argument that tax compliance should not be analyzed under the same umbrella as white-collar crime. This study supports the claim that the behavior of individuals in the context of tax evasion differs from other types of white-collar crime. Specifically, the personality trait of neuroticism showed a significant relationship with tax non-compliance. Past research that considered the overarching umbrella of white-collar crime did not find this relationship. In fact, in certain instances an opposite relationship was uncovered (Turner, 2014). This study aligns with previous findings as to how neuroticism relates with the prediction of unethical behavior. Specifically, higher levels of neuroticism are associated with increased occurrence of less desired behavior. As tax evasion is deemed a less severe type of white-collar crime (Burton, Karlinsky, \& Blanthorne, 2005), this study supports that tax evasion should be removed from the umbrella of white-collar crime as the relationship with personality predictors is explored.

A second contribution is that after controlling for risk and desire to reduce taxes, the addition of personality traits causes a significant improvement in model fit. As tax professionals and government auditors look for ways to make sure that clients and taxpayers are being forthcoming with information understanding that personality can influence the relationship with tax compliance is useful.

A third contribution is made by bringing to light the lack of knowledge that taxpayers have related to the reporting of taxable income. Only $44.7 \%$ of survey respondents (137 out of 306) correctly answered as to the tax law related to reporting income on a tax return. This number combined with the fact that 
$48.2 \%$ of respondents had actually received side income at least once over the previous five years, based on self-reported information gathered from the survey, is alarming. Gaining a better understanding of taxpayer knowledge and how this knowledge can be improved appears to be a fruitful direction for future research.

Despite the above contributions, the study does have several limitations. First, an online survey was used to gather information to attempt to measure taxpayer intent. The results of this research showed that a significant number of taxpayers demonstrate non-compliant behavior. In terms of self-reporting and social desirability bias, the belief would be that respondents would desire to present responses that portray them in a favorable (compliant) manner. This result was not observed as $53.3 \%$ of the sample reported a non-compliant amount. This study did include a measure to control for social desirability. Review of the measure showed no significant influence was found related to social desirability. Thus, said scale was excluded from analysis. Regardless, however, the limitation of the online survey is acknowledged.

Another limitation of this study is controls may exist in real-world filing that restrict a taxpayer from engaging in certain behavior. As an example, some taxpayers use the service of a tax professional when preparing and filing tax returns. This third party may influence or restrict the decision making process of an individual. Based on an information question that was included in this study, $18.2 \%$ of the respondents reported relying on a tax professional. This number helps build belief that within the analyzed sample the majority of respondents answered in a manner that would mirror an actual filed tax return since only a small amount would have relied on advice from a tax professional. For added verification, post-hoc analysis did not show any significant differences in results between whether a taxpayer engaged a tax professional. The possible influence of a third party, although not suspect in this study, is a limitation that we acknowledge.

Despite these limitations, our results suggest implications for future research. First, additional investigation of how personality traits influence taxpayer behavior is warranted. Past studies related to economic crime have produced varied results. For example, Alalehto (2003) referenced a relationship between extraverted individuals and increased economic crime activity, while other studies (including post-hoc analysis within this study) have shown no such correlation (Turner, 2014). In the slightly different context of academic cheating, conflicting results have also been seen (Giluk \& Postlethwaite, 2015). As this study is the first we are aware to look at the narrowed context of individual tax compliance and personality, further research should continue. In addition, personality does not exist in a vacuum. Therefore, looking at how traits interact with other explanatory variables could provide beneficial findings.

A second area of future research could explore the relationship between tax compliance and alternative personality frameworks. This research explored the relationship between tax compliance and the three of the Big Five personality traits. Although this framework attempts to provide an allencompassing measure of personality, limitations do exist (Paunonen \& Jackson, 2000). Specifically, "socially malevolent traits" are not adequately represented in the Big Five model (Veselka, Schermer, \& Vernon, 2012, p. 417). Acknowledging such limitations and the fact that a multitude of personality frameworks exist (e.g., Myers-Briggs Type Indicator ${ }^{\circledR}[\mathrm{MBTI}], \mathrm{A} / \mathrm{B}$ personality types, Big Seven traits, and the Dark Triad personality cluster), added research related to these alternative measures may provide more robust findings in seeking to better understand how personality relates to taxpayer compliance decisions.

Finally, this study brings to light the lack of knowledge that taxpayers have related to the reporting of taxable income. Studies that look at how taxpayers obtain and retain tax law knowledge could prove to be fruitful. 


\section{CONCLUSION}

The goal of this study was to highlight the relationship between the personality traits of neuroticism, agreeableness, and conscientiousness and taxpayer behavior (compliance versus non-compliance). This appears to be the first study to explore this relationship providing support for the personality traits of neuroticism and conscientiousness. Future research needs to continue to explore the how and why taxpayers make decisions. The personality traits of neuroticism and conscientiousness may be a small piece that can contribute to this goal.

\section{REFERENCES}

Alalehto, T. (2003). Economic crime: Does personality matter? International Journal of Offender Therapy and Comparative Criminology, 47(3), 335-355.

Andreoni, J., Erard, B., \& Feinstein, J. (1998). Tax compliance. Journal of Economic Literature, 36(2), 816-860. Retrieved from http://www.jstor.org/stable/2565123

Aust, F., Diedenhofen, B., Ullrich, S., \& Musch, J. (2012). Seriousness checks are useful to improve data validity in online research. Behavior Research Methods, 45(2), 527-535.

Blickle, G., Schlegel, A., Fassbender, P., \& Klein, U. (2006). Some personality correlates of business white-collar crime. Applied Psychology, 55(2), 220-233.

Bobek, D. D., Hageman, A. M., \& Kelliher, C. F. (2013). Analyzing the role of social norms in tax compliance behavior. Journal of Business Ethics, 115(3), 451-468.

Borghans, L., Duckworth, A., Heckman, J., \& Weel, B. (2008). The economics and psychology of personality traits. Journal of Human Resources, 43(4), 972-1059.

Bratton, V. K., \& Strittmatter, C. (2013). To cheat or not to cheat?: The role of personality in academic and business ethics. Ethics \& Behavior, 23(6), 427-444.

Burton, H. A., Karlinsky, S. S., \& Blanthorne, C. (2005). Perception of a white collar crime: Tax Evasion. Journal of Legal Tax Research, 3(1), 35-48.

Collins, J., Milliron, V., \& Toy, D. (1992). Determinants of tax compliance: A contingency approach. The Journal of the American Taxation Association, 14(2), 1-29. Retrieved from http://aaajournals.org/loi/atax

Cortina, J. M. (1993). What is coefficient alpha? An examination of theory and applications. Journal of Applied Psychology, 78(1), 98-104.

Davis, J. S., Hecht, G., \& Perkins, J. D. (2003). Social behaviors, enforcement, and tax compliance dynamics. Accounting Review, 78(1), 39-69.

Donnellan, M. B., Oswald, F. L., Baird, B. M., \& Lucas, R. E. (2006). The mini-IPIP scales: Tiny-yeteffective measures of the Big Five factors of personality. Psychological Assessment, 18(2), 192203.

Elliott, R. T. (2010). Examining the relationship between personality characteristics and unethical behaviors resulting in economic crime. Ethical Human Psychology and Psychiatry, 12(3), 269276.

Funder, D. C. (2001). Personality. Annual Review of Psychology, 52, 197-221.

Giluk, T. L., \& Postlethwaite, B. E. (2015). Big Five personality and academic dishonesty: A metaanalytic review. Personality and Individual Differences, 72, 59-67.

Goldberg, L. R. (1982). From ace to zombie: Some explorations in the language of personality. In J. N. Butcher \& C. D. Spielberger (Eds.), Advances in personality assessment (Vol. 1, pp. 203-234). Mahwah, NJ: Lawrence Erlbaum Associates Inc.

Goldberg, L. R. (1999). A broad-bandwidth, public-domain, personality inventory measuring the lowerlevel facets of several five-factor models In I. Mervielde, I. J. Deary, F. De Fruyt, \& F. Ostendorf (Eds.), Personality psychology in Europe (Vol. 7, pp. 7-28). Tilburg, the Netherlands: Tilburg University Press. 
Hakulinen, C., Elovainio, M., Batty, G. D., Virtanen, M., Kivimäki, M., \& Jokela, M. (2015). Personality and alcohol consumption: Pooled analysis of 72,949 adults from eight cohort studies. Drug and Alcohol Dependence, 151, 110-114.

Hasseldine, J., \& Li, Z. (1999). More tax evasion research required in new millennium. Crime Law and Social Change, 31(2), 91-104.

Hauser, D. J., \& Schwarz, N. (2016). Attentive Turkers: MTurk participants perform better on online attention checks than do subject pool participants. Behavior Research Methods, 48(1), 400-407.

Hessing, D. J., Elffers, H., \& Weigel, R. H. (1988). Exploring the limits of self-reports and reasoned action: An investigation of the psychology of tax evasion. Journal of Personality and Social Psychology, 54(3), 405-413.

Hite, P. (1996). Commentary on an analysis of moral and social influences on taxpayer behavior. Behavioral Research in Accounting, 8, 76-79. http://aaajournals.org/loi/bria

Internal Revenue Service. (2016a). Tax gap estimates for tax years 2008 - 2010. Retrieved from https://www.irs.gov/pub/newsroom/tax\%20gap\%20estimates\%20for\%202008\%20through\%2020 10.pdf

Internal Revenue Service. (2016b). Budget in brief FY 2016. Retrieved from https://www.irs.gov/pub/newsroom/IRS\%20Budget\%20in\%20Brief\%20FY\%202016.pdf

Jackson, B., \& Milliron, V. (1986). Tax compliance research: Findings, problems, and prospects. Journal of Accounting Literature, 5(5), 125-165. Retrieved from https://www.journals.elsevier.com/journal-of-accounting-literature/

John, O., Robins, R., \& Pervin, L. (Eds.). (2008). Handbook of personality: Theory and research (3rd ed.). New York, NY: The Guildford Press.

Judge, T. A., \& Zapata, C. P. (2015). The person-situation debate revisited: Effect of situation strength and trait activation on the validity of the big five personality traits in predicting job pPerformance. Academy of Management Journal, 58(4), 1149-1179.

Kalshoven, K., Den Hartog, D. N., \& De Hoogh, A. H. (2011). Ethical leader behavior and big five factors of personality. Journal of Business Ethics, 100(2), 349-366.

Kolz, A. (1999). Personality predictors of retail employee theft and counterproductive behavior. Journal of Professional Services Marketing, 19(2), 107.

Lin, L. Y. (2010). The relationship of consumer personality trait, brand personality and brand loyalty: an empirical study of toys and video games buyers. Journal of Product \& Brand Management, 19(1), 4-17.

Loftus, E. (1985). To file, perchance to cheat. Psychology Today, 19(4), 34-39. Retrieved from https://www.psychologytoday.com/

McCrae, R., \& Costa, P. (2003). Personality in adulthood: A five-factor theory perspective. New York: Guilford Press.

McCrae, R., \& John, O. (1992). An introduction to the five-factor model and its applications. Journal of Personality, 60(2), 175-215.

McGee, R. W., \& Tyler, M. (2006). Tax evasion and ethics: A demographic study of 33 countries (Working Paper). doi:10.2139/ssrn.940505

Oppenheimer, D. M., Meyvis, T., \& Davidenko, N. (2009). Instructional manipulation checks: Detecting satisficing to increase statistical power. Journal of Experimental Social Psychology, 45(4), 867872.

Paunonen, S., \& Jackson, D. (2000). What is beyond the Big Five? Plenty! Journal of Personality, 68(5), 821-835.

Pervin, L., \& John, O. (Eds.). (1999). Handbook of personality: Theory and research (2nd ed.). New York, NY: The Guilford Press.

Pickhardt, M., \& Prinz, A. (2014). Behavioral dynamics of tax evasion - A survey. Journal of Economic Psychology, 40, 1-19. 
Ragatz, L. L., Fremouw, W., \& Baker, E. (2012). The psychological profile of white-collar offenders: Demographics, criminal thinking, psychopathic traits, and psychopathology. Criminal Justice and Behavior, 39(7), 978-997.

Richardson, M., \& Sawyer, A. (2001). A taxonomy of the tax compliance literature: Further findings, problems and prospects. Australian Tax Forum, 16, 137-320. Retrieved from https://www.taxinstitute.com.au/resources/books-and-journals/australian-tax-forum/australiantax-forum

Ryan, T., \& Xenos, S. (2011). Who uses Facebook? An investigation into the relationship between the Big Five, shyness, narcissism, loneliness, and Facebook usage. Computers in Human Behavior, 27(5), 1658-1664.

Sacket, P. R., \& Wanek, J. E. (1996). New development in the use of measures of honesty, integrity, conscientiousness, dependability, trustworthiness, and reliability for personnel selection. Personnel Psychology, 49, 787-829.

Smith, K. W., \& Kinsey, K. A. (1987). Understanding taxpaying behavior: A conceptual framework with implications for research. Law \& Society Review, 21(4), 639-663. Retrieved from http://www.lawandsociety.org/review.html

Svendsen, G., Johnsen, J., Almas-Sorensen, L., \& Vitterso, J. (2011). Personality and technology acceptance: The influence of personality factors on the core constructs of the Technology Acceptance Model. Behaviour \& Information Technology, 32(4), 323-334.

Taggar, S., \& Parkinson, J. (2007). Personality tests in accounting research. Journal of Human Resource Costing \& Accounting, 11(2), 122-151. Retrieved from http://www.emeraldinsight.com/journal/jhrca

Tett, R. P., Jackson, D. N., \& Rothstein, M. (2001). Personality measures as predictors of job performance: A meta-analytic review. Personnel Psychology, 44(4), 703-742.

Tittle, C. (1977). Sanction, fear, and the maintenance of social order. Social Forces, 55(3), 579-596. Retrieved from https://academic.oup.com/sf

Trivedi, V. U., Shehata, M., \& Lynn, B. (2003). Impact of personal and situational factors on taxpayer compliance: An experimental analysis. Journal of Business Ethics, 47(1993), 175-197.

Tsakumis, G. T., Curatola, A. P., \& Porcano, T. M. (2007). The relation between national cultural dimensions and tax evasion. Journal of International Accounting, Auditing and Taxation, 16(2), $131-147$.

Turner, M. (2014). Big Five personality and propensity to commit white-collar crime. Advances in Accounting Behavioral Research, 17, 57-94.

Veselka, L., Schermer, J. A., \& Vernon, P. A. (2012). The Dark Triad and an expanded framework of personality. Personality and Individual Differences, 53(4), 417-425.

Washburn, M., \& Fischer, M. (2012). The Tax Gap: It's Impact on Accounting Professionals and Academic Curriculum. Journal of Accounting and Finance, 12(5), 26-33.

Webley, P., Cole, M., \& Eidjar, O. P. (2001). The prediction of self-reported and hypothetical taxevasion: Evidence from England, France and Norway. Journal of Economic Psychology, 22(2), $141-155$.

Weigel, R., Hessing, D., \& Elffers, H. (1987). Tax evasion research: A critical appraisal and theoretical model. Journal of Economic Psychology, 8(2), 215-235. Retrieved from https://www.journals.elsevier.com/journal-of-economic-psychology/

Yu, H., Glanzer, P. L., Sriram, R., Johnson, B. R., \& Moore, B. (2017). What contributes to college students' cheating? A study of individual factors. Ethics \& Behavior, 27(5), 401-422. 